\title{
Studying the Petroglyphs of Dash Ancient Complex; Meshgin Shahr, Northwest of Iran (Azerbaijan)
}

\author{
Mohammad Mirzaei $^{1}$, Ali Karimi Kiya ${ }^{2}$, Nasrin Alizadeh $^{3}$, Siyavash Abdollahi ${ }^{4}$, Vahid Ebrahimi ${ }^{5}$ \\ ${ }^{1}$ Department of Archaeology, University of Sistan and Baluchestan, Zahedan, Iran \\ ${ }^{2}$ Department of Archaeology, University of Tehran, Tehran, Iran \\ ${ }^{3}$ Department of Art, Islamic Azad University of Ramsar, Ramsar, Iran \\ ${ }^{4}$ Department of Archaeology, University of Mohaghegh Ardebili, Ardebil, Iran \\ ${ }^{5}$ Department of Archaeology, Islamic Azad University of Miyaneh, Miyaneh, Iran
}

Email address:

mirzaii63@yahoo.com (M Mirzaei)

\section{To cite this article:}

Mohammad Mirzaei, Ali Karimi Kiya, Nasrin Alizadeh, Siyavash Abdollahi, Vahid Ebrahimi. Studying the Petroglyphs of Dash Ancient Complex; Meshgin Shahr, Northwest of Iran (Azerbaijan). International Journal of Archaeology. Vol. 4, No. 3, 2016, pp. 26-30.

doi: $10.11648 /$ j.ija.20160403.11

Received: May 17, 2016; Accepted: May 30, 2016; Published: June 13, 2016

\begin{abstract}
Rock reliefs and petroglyphs as a worldwide art date back to earliest centuries of human history, and are the most basic form of art for human being to express their emotions and observations. Most of the mountainous regions in Iran are embedding petroglyphs related to nomadic life and pastoralism. Dash complex is located on northwest of Iran, on the basin of Qarasu River in Meshgin Shahr county, its motifs are mostly about subsistence of the habitant and we hope to achieve evidences regarding the livelihood of the primary residents of this region. Other sites on the Basin of Qarasu River such as Shahar Yeri, Mashiran, Sheikh Medi and Deveh Deresi are also containing similar and related petroglyphs. Studying "Dash complex" petroglyphs is conducted based on filed surveys and library researches; the petroglyphs are divided into three categories of human, animal and geometric motifs and their connection and association with environmental and livelihood background of the region is subject of the present study analysis.
\end{abstract}

Keywords: Northwest of Iran, Meshgin Shahr, Qarasu River, Petroglyph, Dash Complex

\section{Introduction}

Rock reliefs and petroglyphs as a worldwide art date back to earliest centuries of human history, and are the most basic form of art for human being to express their emotions and observations. Most of the mountainous regions in Iran are embedding petroglyphs related to nomadic life and pastoralism. Dash complex is located on northwest of Iran, on the basin of Qarasu River in Meshgin Shahr county, its motifs are mostly about subsistence of the habitant and we hope to achieve evidences regarding the livelihood of the primary residents of this region. Other sites on the Basin of Qarasu River (Fig. 2) such as Shahar Yeri, Mashiran, Sheikh Medi and Deveh Deresi are also containing similar and related petroglyphs. Studying "Dash complex" petroglyphs is conducted based on filed surveys and library researches; the petroglyphs are divided into three categories of human, animal and geometric motifs and would be analyze. According to researchers, petroglyph and rock art is a universal art and dates back to ancient time and has been considered among the most important types of Visual Arts, expressing the first sparkles of human aesthetic sense and artistic nature of our ancestors all around the world. Ancient rock reliefs which have been created for the variety of reasons are now the most ancient and authentic documents about cultural evolutions and complicated social structure of ancient periods. In fact, ancient societies have left these sign, consciously or unconsciously, as a proof of their existence. This art exist all around the world and is an inseparable part of human art history with a fundamental influence on intellectual and artistic growth and excellence of human societies [13]. The rock arts generally fall into four different categories: Petroglyph, Pictograph, Cupules and Geoglyph [12]. Petroglyph, Cupules and Geoglyph are created by 
carving, engraving, abrasion and hammering while pictographs are mostly painting or literally pictographs made of colorful substances and made by tools like fingers or sticks on a surface. According to historic arts' scholars, reliefs are amongst the most important and mysterious archeological remains and considered them as the "common human language" or "alive historic archive.

\section{The Geographical Location of the Dash Complex}

Dash rock complex (Fig. 1) is located between Dada Beyglou village and Chapaqan village, in Meshgin Shahr County of Ardebil province, with the geographical location of $33^{\circ} 33^{\prime} 45^{\prime \prime}$ and $^{\circ} 51^{\prime} 07^{\prime \prime} 47$ and altitude of $1100 \mathrm{~m}$ on the south of Qarasu River (Fig. 2). The oval shape mountain with numerous boulders laying from east to west, between the two villages is known as Dash, which means stone in Turkish language.

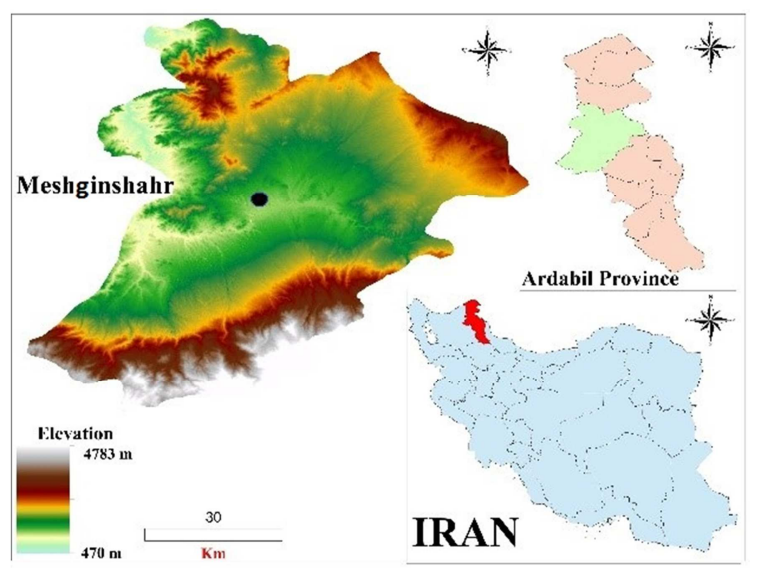

Fig. 1. Dash complex location between Dada Beyglu and Chapaqan villages (authors).

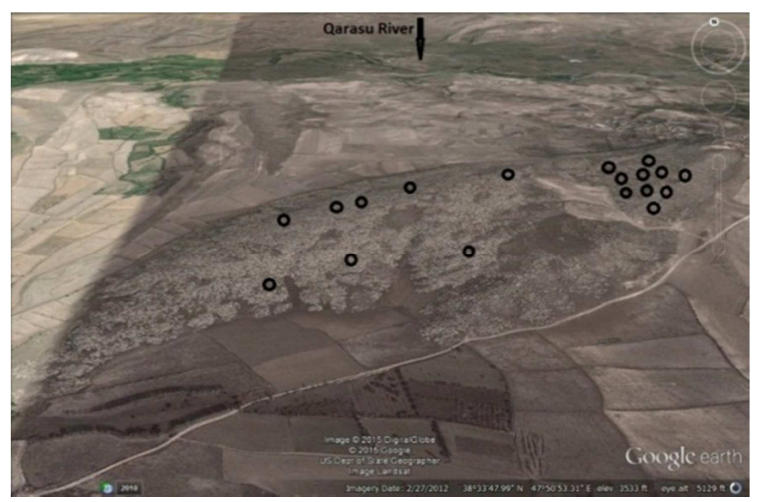

Fig. 2. Distribution of motifs in Dash complex beside the Qarasu River (Google Earth).

\section{Methodology}

Reliefs of "Dash Complex" have been studies though field surveys and library researches and based on an analyticaldescriptive method. Although their dating is not quite clear but according to the available evidences, their creation can be attributed to prehistoric and historic periods until the following periods.

\section{Research Background}

The abundance of rock art in Northwest of Iran has attracted a lot of attention to this region and consequently, many studies have been conducted in this regard such as Arasbaran rock art (Süngün) [9, 10], Rock relief art on northwest of Iran [11], Shahar Yeri rock reliefs [7], Arasbaran rock reliefs (Karimi, 2003) and Duzdaqi rock reliefs on northwest of Iran [8].

Dash complex reliefs which are part of the relief complex of Qarasu River basin complex on northwest of Iran are among Petroglyph, Pictograph or even Cupules with animal, human and geometric motifs. According to archeological finds, northwest of Iran has always been a suitable location for settlements from prehistoric up to now; and rock reliefs of Meshgin Shahr (Qarasu basin) are one of these findings.

\section{Dash Complex's Petroglyphs}

The reliefs were conducted during several days in 2014 and the following results were obtained. The reliefs of this complex are scattered on flat boulders on the mountain's slope. The motifs consists of human, animals, symbolic signs patterns with animal motifs, especially capra (Ibex), in the majority. 34 motifs have been identified up to now which are as follows, 25 animal motifs, 2 human motifs, 5 geometric and 2 person names Mohamad and Shahram motifs (Table 1).

Table 1. The division of Dash Complex petroglyphs (Authors).

\begin{tabular}{lll}
\hline \multicolumn{2}{l}{ A study of Dash Complex petroglyphs } & \\
\hline Motifs & & Divisions \\
\hline \multirow{2}{*}{ Animals } & Goats & 24 \\
Human & Deer & 1 \\
& & 2 \\
Geometry & Line & 1 \\
& Cupule & 3 \\
Inscription & Arc-Shaped Line & 1 \\
Total & & 2 \\
\hline
\end{tabular}

\subsection{Animal Motifs}

The most depicted subject are animals (Fig. 3) that usually standing, gazing or fighting in rows behind each other. Like most of the sites in Iran, the image of ibex is also depicted frequently in Qarasu basin's sites usually in stylized and unnatural way. However there are the depiction of a hoofed animal with a thin body and long horns seems to be gazelle (Fig. 4).

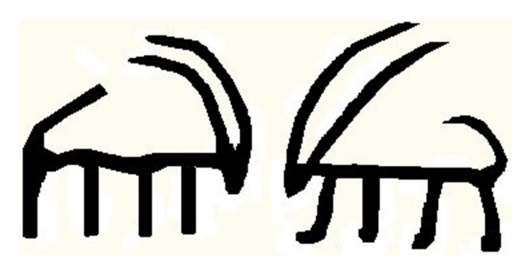




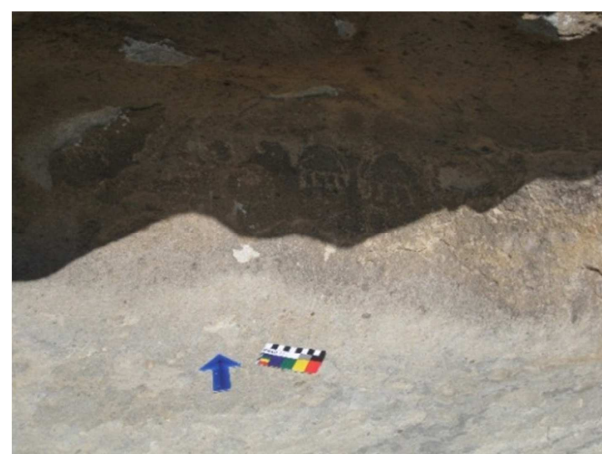

Fig. 3. Two Goats motifs which they are facing each other (authors).

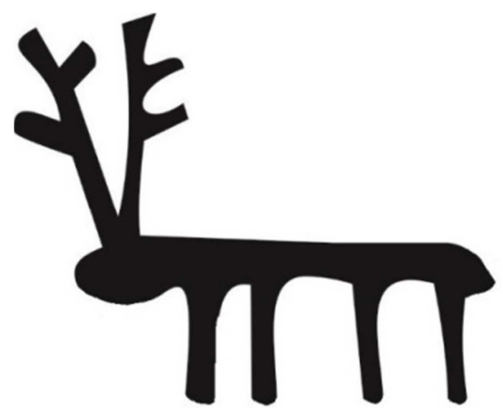

Fig. 4. Gazelle motif in Dash (authors).

\subsection{Human Motifs}
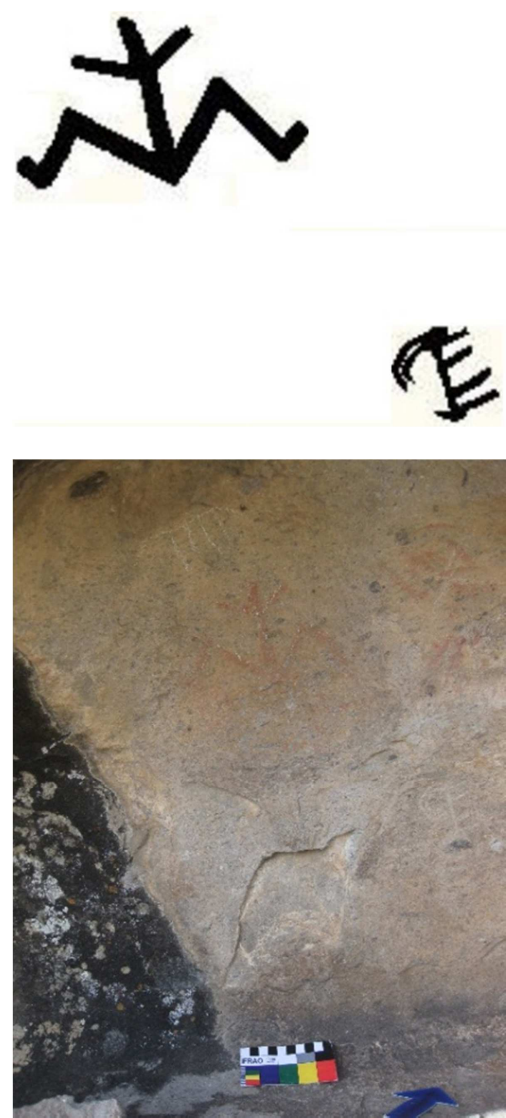

Fig. 5. Human motifs in Dash (authors).

The second group of mentioned complex are human pictographs with red colors. According to researchers, cave inscriptions and painting in rock shelters go back to the most ancient periods of human life. Several samples of pictographs have been discovered in a vast area in northern and central Asia, and Iran which are usually showing scenes of hunting, however, there is no general agreement about their dating.

The red pictographs on rocks are among the major discoveries in Dash complex; regarding their colors, they might have used Iron oxide compounds to create red ocher. The main theme of this paintings are human figures, probably three women while giving birth or squatting (Fig. 5). Two of these pictographs are definitely human motifs but the third one is mostly erased and vague.

\subsection{Geometric, Symbolic Signs and Cupules}

The third group of Dash are Geometric, Symbolic Signs and Cupules. Three motifs contains geometric shapes are the most interesting. This motif consists of 68 small circles which are made by stroking and together shape two ovals; the west, east and north of the shapes are enclosed by a thin stoked line that passed the eastern part of the oval and turns upward, also a deep hole exists under this motif. One of the most important samples is cupules that make as hemispherical depression on the hard rock surfaces (Fig. 6).

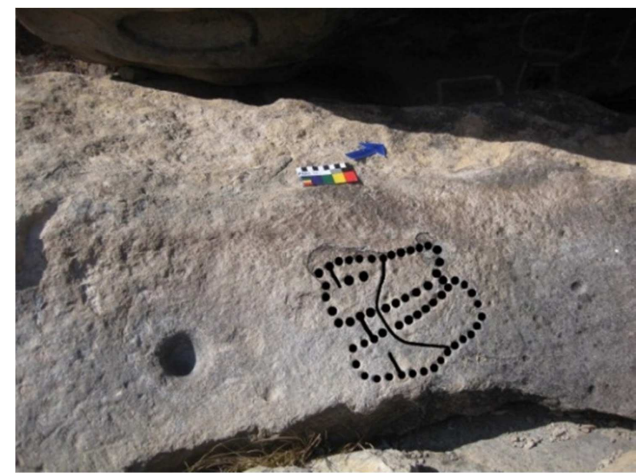

Fig. 6. One of the Cupule in Dash Complex (authors).

The oldest examples currently known date from the Lower Paleolithic [2] Cupules or cup marks or pitted rock have been found in other sites all over the world such as Qobustan world heritage, Böyükdaş Mountains, Kiçikdaş and Cingirdağ. Regarding the size of Dash complex's Cupules, they might have has numerical usage or water collecting (Fig. 7).

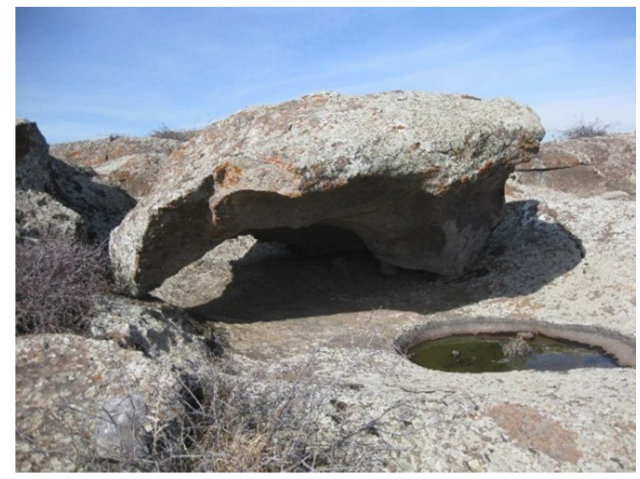



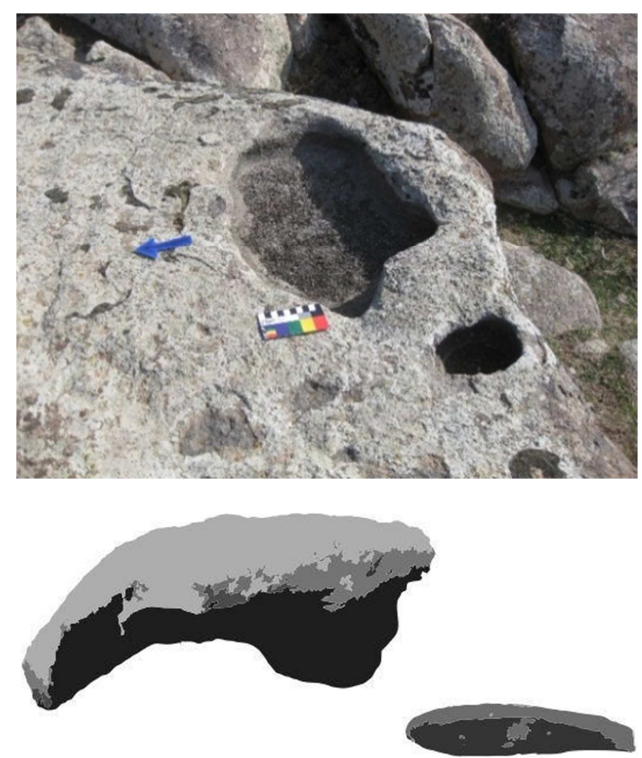

Fig. 7. Cupules in Dash complex (authors).

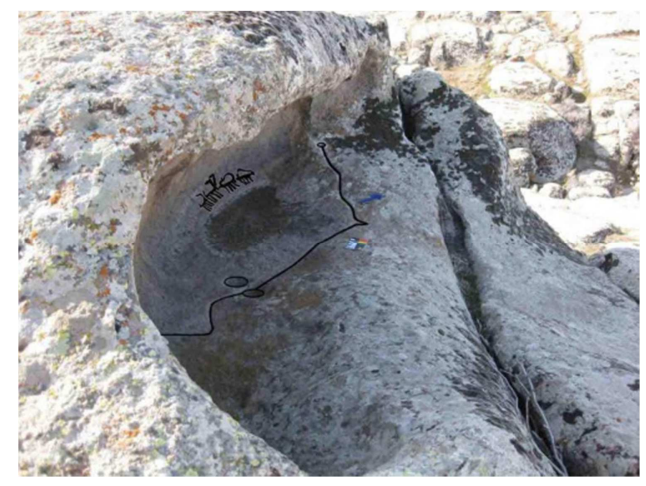

Fig. 8. Arc-Shaped Line in Dash (authors).

Another geometric motif is a stoked circular hollow. There is an arc-shaped line that end of two sides leads down to a small circle (Fig. 8).

\section{The Chronology of Dash Complex Motifs}

Due to the lack of chronological studies about rock arts in Iran, no precise dating about any of the observed rock arts techniques is available. However, comparing the discovered rock arts with the dating of other sites in the same region or other regions is one of the possible solutions. After three decades in chronological rock art but this subject still remains ambiguous [3]. According to Professor Bendarik, cupules are the earliest surviving rock art we know about in the world, it can be date from Middle and even Lower Palaeolithic times in the Old World [4], but there is a need to sufficient experience to estimate their date.

Moreover the pictographs in Dash complex are important features; although dating pictographs is difficult but a relatively correct dating can be achieved through comparing with other similar discoveries in other regions. In Australia, with richest rock art treasury, the results of the pigments analysis showed that they date back to Pleistocene period [5] and in north of Australia according to the precise dating, the pictographs date back to 25000 years age [14], a shelter from Paleolithic was discovered on the southern side of this site as well. The comparison among the human and especially animal motifs including the motifs of goats and deers in Qobustan [6] and Gomi Qaya [1] is probably related to Bronze Age. Other comparable samples with Qobustan are Cupules or rock pits, seeing the depiction of local people names not so long ago are written Arabic inscription such as Shahram Gözali or Mohamad on one of the southern stones of the site is showing that this tradition has been pursued up to recent years. It could be supposed to that's made by shepherds (Fig. 9).

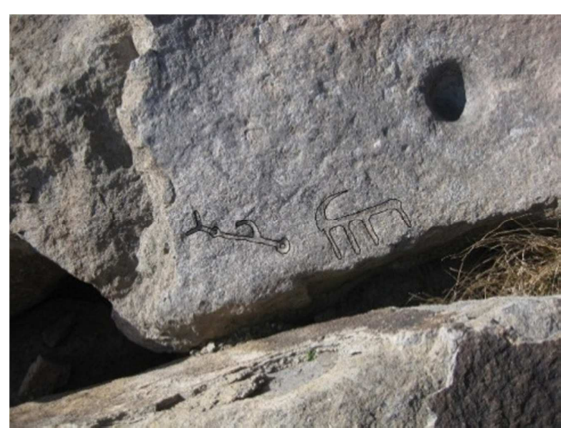

Fig. 9. Depiction of person names (authors).

Due to the lack of chronological studies about rock arts in Iran, no precise dating about any of the observed rock arts techniques is available. However, comparing the discovered rock arts with the dating of other sites in the same region or other regions is one of the possible solutions.

In accordance with some signs like pictography and cupules, cave and two Arabic inscription we can say this complex was in use for a long time period possibly from prehistoric times to the Late Islamic era.

The analysis of depth and weathering of the motifs showed that the dating of northern motifs is more ancient than the southern side.

\section{Conclusion}

The vast territories of Azerbaijan with its rich cultural and ancient remains has provided a suitable context for archeological studies and surveys; meanwhile, Qarasu River's basin with special conditions and strategic location has great importance. Besides the identified ancient Tepes in the Basin of Qarasu River, other related sites with rock arts and petroglyphs on the caves' walls or on the rocks are quite significant in terms of archeological, cultural and artistic point of view. The depictions of different animals show the environmental variety of this region. Dash complex petroglyphs are located between two villages of Dada Beyglu and Chapaqan, containing human, geometric, symbolic and mostly animal motifs. Most of the motifs are showing different scene and probably had been drawn for a reason. The motifs on the northwestern Iran are very similar to the 
discovered motifs in Qobustan in terms of content and style, therefore, comparing the dating between Qabustan sites and Qarasu river basin seems to be a logical strategy. According to the analytical results, Qarasu petroglyphs are revealing the ancient history of the settlements in this region from the Neolithic period up to now and the progressive stages of communities' and nations' life from nomadism and hunting to sedentarization. Therefore, according to the evidences and results of comparisons, it can be inferred that Qarasu River Basin motifs, such as Shahar Yeri, Chapaqan, Nuqdu, Mashiran, Deve Deresi, Sheykh Medi and specially Dash complex date back to prehistoric period and have continued and imitated up to now by local residents. All of these motifs are located in the nomads' territories or nearby them, and the current villages have been constructed around them, although the villages' residents are still migrating in close distances. Thus, the creation of these motifs can be attributed to the pastorals and nomad reflecting their daily livelihood.

\section{References}

[1] Baxşəliyev, Vəli, 2006, Azərbaycan Arxeologiyasi, Elm: Bak1

[2] Bednarik, R. G. (1993). Palaeolithic art in India, Man and Environment 18(2): 33-40.

[3] Bednarik, R. G. 2007. Rock art science: the scientific study of palaeoart, 2nd edn. Aryan International Press, New Delhi (1stedn 2001, Brepols, Turnhout).

[4] Bednarik, Robert G., (2008). Cupules, Rock Art Research, Volume 25, Number 1, pp. 61-100
[5] David, Bruno, Geneste, Jean-Michel, Fiona Petchey, JeanJacques Delannoy, Bryce Barker, Mark Eccleston, (2013). How old are Australia's pictographs? A review of rock art dating, Journal of Archaeological Science, Volume 40, Issue 1, Pages 3-10.

[6] Fərəcova, Məlahət, 2007, «Qobustan Çalaları», Azerbaycan dövlət nəşriyyatı, bakı.

[7] Hurshid, Shaghayegh, (2007). Introducing Shahar Yeri Petroglyphs (Arjaq Castle), Ancient Studies Journal. 3. (In Persian).

[8] Kazempur. M, Eskandari. N, Shafizade A., (2011). The petroglyphsof Dowzdaghi, Northwestern Iran, Documenta Praehistorica XXXVIII, Pp 383-387.

[9] Rafiefar, J (2002). Arasbaran Petroglyphs (Süngün). Anthropology Journal. 1(1). P 44-75. (In Persian).

[10] Rafiefar, J (2005). Arasbaran Petroglyphs. Tehran: Anthropology Research Institute publication. (In Persian).

[11] Rafiefar, J (2009). Rock Art in Northwestern Iran, Hurand (Liqlan) Petroglyphs, Archeology Research Institute publication. (In Persian).

[12] Sinay, Sue, Anne, (2001), «Rock Art Native American Indians Southern California», Manhattan Beach. California, USA.

[13] Tolstoy, Leo (1977). What is Art? (Trans. Dehgan, K). Tehran: Amirkabir. (In Persian).

[14] Watchman, Alan, (1993). Evidence of a 25,000-year-old pictograph in Northern Australia, Geoarchaeology, Volume 8, Issue 6, pages 465-473. 